\title{
РАБОТА ИСТПАРТОВ СЕВЕРНОГО КАВКАЗА В СИСТЕМЕ РЕАЛИЗАЦИИ ПОЛИТИКИ ПАМЯТИ СОВЕТСКОЙ ВЛАСТИ В 1920-е ГОДЫ
}

В статье рассматривается деятельность истпартов Северного Кавказа как акторов реализации политики памяти советской власти в 1920-е годы на локальном уровне. Обращается внимание, что политика памяти выступает в качестве основы для формирования и поддержания идентичности и связана с выработкой и утверждением социальных представлений о прошлом. Анализируется приоритетное направление реализации политики памяти истпартами, связанное с коммеморацией исторических событий, выбор которых определялся значимостью с точки зрения легитимизации власти большевиков в общественном сознании. Среди них были общесоюзные революционные юбилеи, коммеморация которых должна была, как транслировать идеи центра, так и отражать локальные особенности. Кроме того, рассмотрено участие истпартов в подготовке юбилейных мероприятий, посвященных истории местных вех революционного движения.

На основе анализа комплекса инструктивных, делопроизводственных и отчетных документов выявле- ны основные способы реализации политики памяти истпартами Северного Кавказа. Истпарты занимались организацией выставок и музеев революции; участвовали в проведении торжественных заседаний и вечеров воспоминаний; сотрудники выступали с докладами на собраниях в партийных ячейках на предприятиях, в избах-читальнях, красных уголках и библиотеках; публиковали материалы в периодической печати; издавали плакаты и лозунги; торжественно открывали мемориальные доски; выпускали и распространяли издания по историко-революционной тематике; проводили занятия в школах. Автор приходит к выводу, что истпарты как мнемонические акторы не только создавали интерпретации истории по партийным мотивам, но и предпринимали практические меры с целью убедить общественность в правильности интерпретаций.

Ключевые слова: истпарт, политика памяти, историческая память, общественное сознание, советская идеология, Северный Кавказ.

V. Klopikhina

The article discusses the activities of isparts in the North Caucasus as actors of memory policy of the Soviet power in 1920-s at the local level. Attention is drawn to the fact that the memory policy serves the basis for the formation and maintenance of identity and is associated with the development and approval of social ideas about the past. The article analyzes the priority direction of the memory policy as actualized by the isparts: the commemoration of historical events. The choice of the latter was determined by the significance from the point of view of legitimization of the Bolsheviks' power in the public consciousness. They also included the all-Union revolutionary anniversaries, the commemoration of which was to both broadcast the ideas of the center and reflect local peculiarities. In addition, the article studies the participation of isparts in the preparation of jubilee events dedicated to the history of the local milestones of the revolutionary movement.

Based on the analysis of complex guidance, record keeping and reporting documents, the basic methods of

В современной России в связи с запросом общества на формирование общероссийской идентичности, обусловленным социокультурными, экономическими и внешнеполитическими implementing the memory policy as used by isparts in the North Caucasus are specified. Isparts were involved in the organization of exhibitions and museums of the revolution; they participated in carrying out solemn meetings and evenings of recollections; the staff made presentations at meetings of party cells at the enterprises, in reading rooms, red corners and libraries; published papers in periodicals; published posters and slogans; solemnly opened memorial plaques; they produced and distributed publications on historical and revolutionary themes, conducted classes in schools. The author comes to the conclusion that isparts as mnemonic actors not only created the interpretation of history by party motives, but also took practical measures to convince the public of the correctness of interpretations.

Key words: istpart, politics of memory, historical memory, social consciousness, Soviet ideology, the North Caucasus.

условиями жизни страны, актуализирована деятельность государства по реализации политики памяти. Политика памяти, являясь основой формирования и поддержания идентичности, 
связана с выработкой и утверждением социальных представлений о прошлом и может осуществляться различными способами: сооружением памятников, организацией музеев, учреждением новых праздников, созданием научных, образовательных, общественных, просветительских институтов, приоритетным финансированием исследований по определенной исторической проблематике, регулированием доступа к архивам и др. По словам исследователей, в условиях идентификационного кризиса история является «экзистенциальным пространством, в котором личность заново находит свою идентичность, смысл своего существования, основу для объединения с общностью» $[15$, с. 72$]$.

Обращение к историческим примерам конструирования социальной реальности на основе обращения к прошлому с применением современного методологического инструментария и терминологии позволяет проанализировать механизм создания образов прошлого, а также их использование для манипуляции массовым сознанием при решении задач идеологического характера. Особый интерес в связи с этим вызывает изучение способов реализации политики памяти при создании новой модели видения смысла социального мира на основе интерпретации истории в период становления советской политической системы.

Политика памяти осуществлялась советской властью многообразными методами и средствами и через различные организационные структуры с целью формирования новой коллективной идентичности. Одним из таких институциональных органов был созданный в 1920 г. Истпарт. Истпарт являлся научно-исследовательской и пропагандистской организацией, занимавшейся сбором, хранением, научной обработкой, изданием и популяризацией материалов по истории Октябрьской революции, Гражданской войны и Коммунистической партии. Также была образована сеть региональных истпартов, в том числе на территории Северного Кавказа. Функционирование Истпарта с 1921 г. в качестве отдела ЦК РКП(б), а региональных истпартов -отделов местных партийных комитетов с одновременным подчинением центральному Истпарту, определило содержание их работы как канала трансляции идей правящей партии в общественную среду. Это было механизмом, позволявшим включить в процесс реализации политики памяти пространство всей страны [3]

Изучение деятельности истпартов как акторов реализации политики памяти позволяет определить механизм создания социальных представлений о прошлом и формирования новых советских символов. По словам И. М. Савельевой и А. В. Полетаева, методологические подходы к трактовке «исторической памяти» в контексте политики памяти трактуются «как функция власти, определяющей, как следует представлять прошлое» [40, с. 57].

В системе работы истпартов происходило формирование новой модели исторической памяти, фундаментом которой было создание исто- рико-революционного нарратива. Помимо этого деятельность истпартов имела практические направления по реализации политики памяти на основе комплекса пропагандистских мероприятий. Несмотря на то, что функциональные принципы работы истпартов предполагали унификацию в масштабах всей страны и в течение 1920-х гг. происходил процесс выработки единой структуры, общих цели и задач деятельности истпартов, в их работе находила отражение и локальная специфика, обусловленная многообразием природно-географических, культурных и социально-исторических составляющих локальных сообществ. Таким образом, рассмотрение работы истпартов Северного Кавказа в рамках политики памяти советской власти позволяет с одной стороны, изучить механизм распространения идей центра, с другой - выявить в их деятельности отражение локальной специфики.

Изучение работы истпартов Северного Кавказа в системе реализации политики памяти советской власти вызвало необходимость обращение к научным трудам, посвященным теоретическим и методологическим проблемам политики памяти. В настоящее время исследования в этой области носят междисциплинарный характер и являются предметом внимания социологов, политологов, философров, историков. В работах А. И. Миллера, Д. В. Ефременко, О. Ю. Малиновой проанализированы разработанные в современной науке основные методологические инструменты изучения политики памяти. По словам исследователей, политика памяти является неизбежной и выступает в качестве одного из важнейших инструментов формирования идентичности [20].

Важным для понимания способов осуществления политики памяти является рассмотрение научных трудов зарубежных и отечественных авторов, посвященных значению праздников в системе социального конструирования реальности. Так, П. Бергер и Т. Лукман рассматривали праздники как способы поддержания легитимности [1]. В концепции П. Бурдье праздник является инструментом социальной интеграции [4]. В. Н. Ефремовой проанализированы теоретические подходы к изучению государственных праздников и их роль в символической политике, включающей политику памяти [16]. Советская праздничная культура изучена в работах Г. А. Бордюгова, М. Рольфа и др. [2; 38].

Истпарт и система региональных истпартов не только должны были обеспечить новую модель исторической памяти источниковой базой и новой исторической концепцией, но также принимать активное участие в популяризации своих разработок. Анализ инструктивно-методических материалов истпартов Северного Кавказа позволяет установить, что сами истпарты рассматривали содержание своей деятельности не в качестве «академического научно-исторического органа», а как «историко-пропагандистский аппарат» партии. В соответствии с таким подходом работа истпартов должна была быть «популярна», связана с 
главнейшими событиями партийной жизни и приурочена к ним, а также «общественна» $[32$, л. 1] На местах истпарты тесно взаимодействовали с отделами агитации и пропаганды. Уже в первые годы своей деятельности они «обслуживали» агитпропы, его сотрудники составляли тезисы к докладам об исторических событиях; предоставляли материалы для периодической печати в дни агитационных кампаний [21, с. 234]. В то же время в организационной работе истпартов участвовали и сотрудники агитпропов, что непосредственным образом отражалось и на содержательной стороне функционирования истпартов

Приоритетным направлением реализации политики памяти истпартами являлась коммеморация исторических событий, выбор которых определялся значимостью с точки зрения легитимизации власти большевиков в общественном сознании. В первое десятилетие советской власти шел процесс поиска таких юбилейных дат Следуя терминологии Э. Хобсбаума и Т. Рейнджера, это было временем «изобретения традиции" [52]. Соответственно, в фокусе внимания оказались историко-революционные события То, что еще вчера для большинства страны было связано с бедствиями, братоубийством, разрухой, падением морали, новая власть стремилась представить как благо, сформировать мнение о значимости революционного способа преобразования действительности. Происходило навязывание сверху консенсуса относительно смысла социального мира

Коммеморация исторического события становилась актом торжества, предполагающим отмечания, а новые юбилейные даты - способом трансляции идеологических целей власти. Приоритетное внимание уделялось общесоюзным революционным юбилеям, поводом для которых являлись «круглые даты». Наряду с общесоюзными годовщинами, истпарты принимали участие в освещении местных юбилеев, посвященных революционному движению. Таким образом, при формировании новой модели исторической памяти должна была найти отражение локальная специфика

Изучение деятельности истпартов Северного Кавказа позволило установить, что основными способами реализации политики памяти являлись организация выставок и музеев революции; проведение торжественных заседаний и вечеров воспоминаний; выступления с докладами на собраниях в партийных ячейках на предприятиях, в избах-читальнях, красных уголках и библиотеках; газетные кампании; издание плакатов и лозунгов; торжественные открытия мемориальных досок; выпуск и распространение изданий истпартов по историко-революционной тематике проведение занятий в школах. Интенсивность работы зависела от множества ффакторов, в том числе связанных с материальными и кадровыми ресурсами истпартов

Одним из способов реализации политики памяти была организация истпартами выставок и музеев революции, открытие которых приурочивалось к юбилеям революционных событий. Тем самым трансформировалось понимание роли музеев. Визуальное воздействие на сознание малограмотных местных жителей производило сильный пропагандистский эфффект. Подготовка выставок требовала аккумуляции материалов по историко-революционной проблематике, их систематизацию и подготовку к экспонированию для возможности использования в качестве средства влияния на массовое сознание. Именно это находилось в сфере компетенции местных истпартов.

Центральным событием, подлежащим коммеморации, являлась Октябрьская революция На местах празднование годовщин Октябрьской революции началось в 1922 г. Именно в преддверии пятилетнего юбилея на Северном Кавказе были созданы первые выставки истпартов. Так, в Терской губернии в 1922 г. была организована выставка местного истпарта в помещении «Рабочего Дворца» и занимала одну комнату. Несмотря на то, что основная идея образования подобных выставок состояла в размещении там материалов по истории Октябрьской революции, в ее экспозициях были представлены коллекции археологических раскопок, старинных книг и манускриптов. Тем самым прокламации партии большевиков находились вместе с «первобытными древностями» эпохи неолита [35, л. 119]. Это объясняется тем, что созданием и руководством Терского истпарта в это время занимался местный интеллигент-гуманитарий старой школы, который был сотрудником Северо-Кавказского института краеведения и членом Российской Академии Истории материальной культуры - В. Апухтин.

Историко-революционная выставка была образована Кубано-Черноморским истпартом в 1922 г. в одном из залов здания архивного бюро, реорганизованная позже в музей революции. В ее создании также отразились интересы местного руководителя истпарта - сотрудника архивного бюро Е. Полуян-Верецкой. Выставка получила название «Выставка-музей истории Революции на Кубани). Работа по систематизации экспонатов, составлению каталогов и проведению экскурсий осуществлялась самими архивистами. Выставку посещали организованные экскурсии советских и партийных работников, учащихся и крестьян. По имеющимся отчетным данным в течение 1923 г. выставку посетили около 6000 человек [19].

В 1922 г. Донским истпартом была организована временная выставка [7]. В 1924 г. выставку попытались сделать постоянной. Ее экспозиции в это время были представлены 70 «фотографиями в плакатах», 38 отдельными фотоснимками, автографрами, телеграммами, плакатами, протоколами рабочих и крестьянских собраний [6]. Однако в том же году она была закрыта из-за ремонта помещения. На Ставрополье выставка истпарта была создана в 1924 г. при Ставропольском народном музее им. Г. К. Праве. На ней были представлены архивные материалы преиму- 
щественно бывшего жандармского управления, а также документы, относящиеся ко времени Гражданской войны [14].

Выставки истпартов также создавались в «уголках Ленина» в рабоче-крестьянских клубах и избах-читальнях. Экспозиции выставок истпартов отражали не только историю революционного движения. Важным являлось наличие в них материалов, демонстрировавших достижения советской власти. Это были преимущественно диаграммы производственных достижений, которые должны были выполнять функцию создания позитивного образа правящей партии в общественном сознании.

Однако у региональных истпартов в большинстве своем отсутствовал опыт организации музейно-выставочного дела. Четких же инструкций из центра изначально не было. Истпарт ограничивался только общими призывами к организации выставок как средства воздействия на массовое сознание. Ситуация начинает изменяться только после создания в Москве Музея Революции, который становится центром координации этого направления деятельности истпартов [24].

Анализ делопроизводственных материалов истпартов Северного Кавказа показывает, что истпарты в первые годы своего функционирования проявляли инициативу в определении тематики юбилейных мероприятий. К середине 1920-х гг. по мере становления основных принципов советской политической системы эта тематика начинает ограничиваться и корректироваться инструктивными указаниями центрального Истпарта.

В центре дискуссии в 1924 г. оказался столетний юбилей восстания декабристов. Дело в том, что Терский истпарт запланировал проведение на 1925 г. совместного юбилея революции 1905 г и столетнего юбилея восстания декабристов. После обсуждения этого вопроса в центральном Истпарте было решено, что подобное соединение двух юбилейных дат невозможно, т.к. «нельзя смешивать в одно абсолютно не сходные между собой явления и события» $[37$, л.23].

В ноябре 1924 г. все региональные истпарты получили инструктивное письмо центрального Истпарта. В нем критиковалась «излишняя увлеченность" некоторых истпартов юбилеями событий, которые, по мысли центра, не являлись революционными праздниками. В их числе были 150-летие «Пугачевского движения» и 100-летие восстания декабристов. В инструкции признавалось, что «Пугачевское движение» и восстание декабристов занимают свое "особое место» в истории, но не имеют ничего общего с историей РКП(б) и пролетарской революции. Истпартам настоятельно рекомендовалась сосредоточить свое внимание над материалами по истории партии и Октябрьской революции $[29$, л. 4].

В компетенции истпартов согласно директиве из центра была организация к двадцатилетнему юбилею революции 1905 г. и к будущему десятилетию Октябрьской революции $[29$, л. 4]. Именно при подготовке к этим юбилеям истпарты проде- лали основательную работу по реализации основных направлений политики памяти.

Организационные мероприятия, посвященные двадцатилетнему юбилею революции 1905 г., начались в конце 1923 г., и в подготовке к предстоящим торжествам Истпарту отводилось одно из центральных мест. В июне 1924 г. состоялось первое заседание комиссии президиума ЦИК СССР по организации празднования двадцатилетней годовщины 1905 г., на котором Первая российская революция была охарактеризована как «определенный этап в революционном развитии» [17].

Bce юбилейные мероприятия на местах осуществлялись под руководством специально создававшихся краевых, областных и окружных комиссий, в состав которых входили представители истпартов. Такие комиссии были учреждень для организации празднования двадцатой годовщины революции 1905 г. [11; 31, л. 19]. Во всех пропагандистских материалах она была названа «генеральной репетицией Октября», что должно было создавать представление о закономерности Октябрьской революции, а, следовательно, ее легитимности.

Подготовка к двадцатилетнему юбилею революции 1905 г. способствовала активизации работы истпартов по всем направлениям их функционирования. Комиссии составляли планы проведения празднования годовщин. В плань любого отдела истпарта входили проведение вечеров воспоминаний; постановка инсценировок или спектаклей; чтение докладов в школах политграмоты, кружках, избах-читальнях, клубах, в красных уголках на заданные темы; организация выставок; публикация статей по соответствующей тематике в местной периодической печати; издание популярных листовок о юбилейном событии и лозунгов-плакатов, просмотр революционных кинофильмов. Однако возможности для реализации планов были ограниченными.

Прежде всего, для осуществления всех способов реализации политики памяти необходимы были исторические источники, отражавшие локальную специфику по историко-революционной проблематике. 6 декабря 1923 г. был выпущен специальный циркуляр Истпарта ЦК РКП(б), в котором содержалось требование к местным истпартам заняться сбором и обработкой материалов по истории революции 1905 г. С этой целью предлагалось, в первую очередь, изучить архивы канцелярии губернатора, жандармские, полицейские и судебные архивы. Надо было выявить в губернских публичных библиотеках имевшиеся там большевистские и меньшевистские газеты, журналы и брошюры. На всю найденную прессу необходимо было составить описи и переслать ее копию в Истпарт для использования при составлении библиографических справочников по изданиям 1905-1906 годов. В описи указывались название, время первого появления издания и прекращения его выхода, периодичность издания, место хранения и наличие дубликата [49]

Кроме того, истпарты должны были подготовить исторические очерки к этой юбилейной дате 
[38, л. 24]. Издательская деятельность истпартов согласно постановлению президиума ЦИК СССР от 2 января 1925 г. и распоряжению Главлита наркомата просвещения от 31 июля 1925 г подвергалась тщательной проверке. Комиссия Президиума ЦИК по организации празднования двадцатилетней годовщины революции 1905 года имела право всестороннего контроля и предварительной санкции при выпуске всей литературной, музыкальной и кино-продукции по теме революции 1905 г. [12]. Тем самым конструирование новой модели исторической памяти как основы советской идентичности было поставлено под партийный контроль.

В провинции издание юбилейной литературы как средства реализации политики памяти было особенно сложным. Северо-Кавказский краевой истпарт запланировал проведение обширной работы в этом направлении. Однако реалии функционирования истпарта не позволили воплотить ее в жизнь. Не хватало профессиональных кадров для подготовки юбилейных публикаций, слабой была разработка источниковой базы, отсутствовала ясность в методологических подходах, которые сводились к идеологическим лозунгам. Кроме того, истпарт располагал небольшими финансовыми возможностями.

Говоря о работе истпартов, приуроченной двадцатилетнему юбилею революции 1905 г. следует отметить серию мероприятий Донского истпарта. В частности, был организован цикл занятий в школах, тематика которых содержала такие проблемы, как причины революции 1905 г. значение III съезда партии большевиков для подготовки революции, уроки революции и причины ее поражения. Отражением внутрипартийной борьбы за власть, в ходе которой интерпретация истории была одним из способов идейного противостояния, являлась тема о двух тактиках и позиции Л. Троцкого в революции 1905 г. [31, л. 27]. Для студенческой аудитории была использована такая форма пропаганды идей партии как митинги, на которых освещались события революции 1905 г. с точки зрения идеологии [31, л. 24]

Интерес представляет такая фоорма пропаганды как инсценировка публичных судов. Так, сотрудники Донского истпарта приняли участие в организации публичного суда над бывшим градоначальником г. Ростова-на-Дону в столовой Ленинских мастерских В. В. Макеевым, который подавил восстание рабочих в 1905 г. По результатам публичного суда бывший градоначальник был осужден на пять лет заключения [31, л. 25].

Подготовка к двадцатилетнему юбилею революции 1905 г. в 1925 г. и десятилетию Октябрьской революции в 1927 г. способствовали более интенсивному вниманию истпартов к выставочной работе. Именно в это время прослеживается стремление преобразования выставок в музеи революции. В 1925 г. Северо-Кавказский крайком РКП(б) принял постановление о создании краевого музея революции, функционирование которого преследовало выполнение двух задач. Во-пер- вых, он должен был заниматься научно-исследовательской работой. Во-вторых - являться центром, знакомившим «широкие массы» с историей партии и революционного движения на Северном Кавказе [43, л. 5].

При создании выставок и музеев революции истпарты сталкивались с материальными и техническими трудностями. В первую очередь необходимо было найти помещения. Так, Северо-Кавказский крайком РКП(б) принял целый ряд постановлений в январе, феврале, марте и июне 1925 г. по вопросу о выделении помещения для краевого музея революции. И только в июне краевому истпарту для создания музея выделили две комнаты в помещении Делового клуба, хотя партийные постановления предусматривали четыре комнаты $[44$, л. 2]. В итоге музей революции Северо-Кавказского краевого истпарта расположился в одной комнате Делового клуба [44, л. 12].

Одной из форм пропагандистской работы региональных истпартов были вечера воспоминаний, которые являлись не только способом сбора мемуарных источников, но и средством популяризации идеологии партии большевиков. Не случайно они, как правило, приурочивались к юбилейным дням важнейших революционных событий как в России в целом, так и в северокавказском регионе в частности. Тем самым их значение на местах понималось изначально шире, чем возможность сбора воспоминаний. С помощью этих вечеров в массовое сознание внедрялись новые ценности и интерпретация исторического процесса, что помогало сконструировать представления людей об истории в соответствии с новой моделью исторической памяти.

Так, истпарт в Терском округе запланировал не просто мероприятия по празднованию юбилея Первой русской революции, но и характер материалов, которые должны быть задействованы на вечерах воспоминаний. Это - всеобщая забастовка, восстание на броненосце «Потемкин», восстание на Пресне, демонстрация на похоронах Н. Баумана, манифест 17 октября, организация Совета рабочих депутатов, забастовка в Минеральных Водах $[12$, л. 6]. Из перечня исторических событий, отобранных Терским истпартом для пропаганды революции, очевидно, что большая часть материала относилась к событиям в столицах и лишь один материал из восьми к истории местных революционных событий

Еще одной формой пропагандистской работы истпартов была публикация исторических сюжетов в местной периодике. В этом случае поводом также была та или иная юбилейная революционная дата. В инструктивных материалах центрального Истпарта имелось прямое указание на то, что фиксация воспоминаний, систематизация и публикация уже собранных материалов должны были в первую очередь использоваться в целях популяризации [32, л. 1].

Масштаб пропагандистской работы можно увидеть на примере истпартовских публикаций в местной донской печати в связи с юбилеем 
революции 1905 г. Всего за декабрь 1925 г. в газете «Молот» и в «Советском Юге» было издано более 40 юбилейных материалов, около 20 фотографий, рисунки. Примером обобщающих юбилейных статей были статьи под названием «Крестьянство в первой русской революции», «Пролетариат и буржуазия в революции 1905 г.», «Донские казаки в 1905 г.», «Как усмирялась революция 1905 г.» и др. [31, л. 21, 22]. На Ставрополье по случаю празднования двадцатилетней годовщины революции 1905 г. в совокупности был издан 31 материал, среди которых были статьи, воспоминания и хроники, написанные на основе архивов. Этому событию был посвящен специальный номер журнала «Ставрополье» [9, л. 15]. Bce эти публикации были подчинены созданию нового историко-революционного мифа.

Одной из форм участия истпартов в юбилейных мероприятиях была разработка тезисов по историко-революционной проблематике, предназначенных для пропаганды «выдающихся» революционных событий среди трудовых масс. Определялся круг источников, на которые надо было опираться при составлении этих тезисов. К ним относились материалы, находившиеся в распоряжении политической секции местного архивного бюро, чаще всего “жандармские» и “охранные» дела, газеты того периода; прокламации; воспоминания участников. Сотрудники истпартов на основе этих тезисов подготавливали юбилейные доклады, выступления на вечерах воспоминаний, публиковали в прессе юбилейные исторические материалы [38, л. 22]

Рассматривая публикации в периодической печати как одну из форм пропагандистской работы истпартов, следует отметить, что статьи на историко-революционную тематику выходили в канун всех значимых для новой власти революционных дат. Особенно много их было опубликовано в годы «круглых» юбилеев. Важными, по мнению власти, такие публикации были в техрегионах, «где в 1905г революционного движения не было или где оно получило слабое отражение» $[8, \pi .50,51]$.

Одной из форм пропагандистской работы была перепечатка материалов из центральных изданий. В них, как правило, было мало конкретных фактов, а превалировали идеологические суждения. Такими были, например, статьи в том же журнале “Ставрополье» «Значение революции 1905 года» и «Уроки Московского восстания 1905 г.», положения которых были образцами для издательской работы местных истпартов. В частности, революция 1905 г. рассматривалась как репетиция революции 1917 г. [41]. В статьях же истпартовцев было больше фактических данных местного значения, но идеологические установки соответствовали схеме центра. В периодике публиковались также воспоминания участников революционного движения. Их число значительно превосходило объем публицистических статей. Фактически мемуарный материал восполнял нехватку пропагандистских статей. С другой стороны, воспоминания могли создать «живую» карти- ну революционных событий, а это эмоционально воздействовало на читателя. Эмоционально-психологическая сторона была важной составляющей агитационно-пропагандистской работы.

В 1920-е годы официальная модель исторической памяти только складывалась, а унификация гуманитаристики не достигла еще своей вершины, как в 1930-е годы, поэтому в интерпретации революционных событий могли встречаться противоречия. Так, при освещении истории 1905 г. расхождения встречались в публикациях в одной и той же газете. Например, в номере газеты «Власть Советов», посвященной юбилею революции, был помещен на первой странице материал некоего Н. Т. (без указания точной фамилии) «1905 год", в котором отмечалось, что несогласованность действий пролетариата и крестьянства в Первую российскую революцию являлось причиной ее поражения. Рядом же располагалась статья, в которой говорилось со ссылкой на Л. Б. Каменева, что уже в 1905 г. существовал боевой союз рабочих и крестьян под руководством пролетариата [5].

Наиболее широко отмечались в стране ежегодные годовщины Октябрьской революции, в организации которых принимали активное участие местные истпарты. Первая “круглая» дата Октября - десятилетие революции - стала особенно мощным стимулом для пропаганды советских идей. В соответствии с указаниями центра в октябре 1926 г. постановлением секретариата Северо-Кавказского крайкома ВКП(б) была создана комиссия по проведению десятилетней годовщины Октябрьской революции в регионе, в состав которой входил и заведующий краевого истпарта А. Лиманский $[45$, л. 2]. В округах края также при местных исполкомах были созданы подобные комиссии.

Подготовка к юбилею на целый год стала основным содержанием пропагандистской работы истпартов. На местах выявляли участников революционного движения и Гражданской войны, павших и живых. Необходимость пропагандистской «реализации исторических документов» активизировала деятельность по организации выставок и изданию публикаций [34, л. 1]. Центр требовал от истпартов организации юбилейных выставок, подготовив схему их структуры. Выставка должна была состоять из пяти разделов. В первом должна была располагаться характеристика старого режима, а во втором - события Февральской революции. Октябрьская революция и Гражданская война шли самостоятельными разделами. Наконец, пятый отдел должен был быть посвящен социалистическому строительству. Вместе с тем, учитывая ограниченные возможности провинциальных истпартов, допускалось сведение всех разделов в один, но с обязательной демонстрацией предпосылок революции и ее итогов [51].

Вышестоящие инструкции касались и содержания при организации выставок. На первый план нужно было выдвигать материалы, раскрывавшие действия рабочих и крестьянских масс. 
С помощью изобразительных средств надо было подчеркивать руководящую роль пролетариата и значение его политического союза с крестьянством. Необходимо было оттенить организующую роль пролетарского авангарда - ВКП(б). Массы и партии должны были быть представлены «в динамическом разрезе - процессе непрерывной борьбы, острых классовых столкновений». Требовалось демонстрировать социально-экономическую основу революционных битв, одержанных побед и понесенных поражений [51].

Именно в связи с десятилетием Октябрьской революции истпарты в ряде регионов смогли на базе выставок открыть музеи революции в основном за счет местных средств. Такие музеи появились в Ставрополе, Таганроге, Владикавказе Новороссийске [49, л.8]. В тот момент они практически не были связаны с краевым музеем революции, который переживал тяжелые времена. Дело в том, что в феврале 1927 г., несмотря на подготовку к десятилетнему юбилею Октябрьской революции, Северо-Кавказский крайком ВКП(б) в своем постановлении разрешил временное закрыть краевой музей революции, предусматривая возможность его открытия в дальнейшем [46, л. 4]. Это решение было обусловлено отсутствием финансирования, т.к. на 1927/1928 гг. музей не включили в бюджет края [49, л. 8]. Выделение помещения для музея революции также оставалось проблемой

В течение двух лет рассматривался вопрос открытия краевого музея революции. В декабре 1927 г. было решено для создания музея революции передать здание сельскохозяйственной выставки после завершения ее работы $[47$, л. 5] В мае 1928 г. Северо-Кавказский крайком ВКП(б) постановил выделить истпарту на организацию музея революции одну тысячу рублей $[48, \pi .6]$ Однако к «окончательному оформлению» краевого музея революции приступили только с 1929 г. когда была начата работа по учету экспонатов и разработке схем отделов [26, с. 305].

Попытка организации выставки к десятилетию Октябрьской революции была сделана в Терском округе Северо-Кавказского края по инициативе уполномоченного краевого истпарта, заведующего местным архивным бюро. Однако идею создания выставки из-за материальных сложностей в это время не удалось реализовать $[13$, л. 5]. Только в 1929 г. музей революции был создан в помещении местного архивного бюро [42, л. 6-9].

В разных округах Северного Кавказа истпарты участвовали в организации празднования десятилетия Октябрьской революции в многообразных формах. Так, на Кубани в период с 15 сентября по 7 ноября 1927 г. истпарт провел цикл радио-лекций на темы, охватывающие весь период революционной борьбы и Гражданской войны на Кубани. Для ознакомления «трудящихся масс» с историко-революционными местами в период с 1 октября по 7 ноября по этим местам были проведены экскурсии, а также проведен цикл докладов по истории «Гражданской борьбы на Куба- ни». Такие доклады были прочитаны и на рабочих собраниях по всему краю [33, л. 30].

Десятилетие Октябрьской революции по указанию сверху широко освещалось в местной периодической печати. В публикациях в массовое сознание внедрялась идея научности революционного способа преобразования действительности, морально оправдывалось революционное насилие, а также неизбежность и закономерность прихода к власти большевиков. По указаниям Истпарта значительное место в работе местных истпартов занимала подготовка и издание популярной литературы. Формирование регионального исторического нарратива об Октябрьской революции 1917 г. и его трансляция в историческую память в связи с юбилейными датами является самостоятельной проблемой исследования [18].

В январе 1928 г. истпарты получили инструкцию, которая подтверждала одно из существенных направлений их деятельности. В соответствии с директивой центра работники истпарта обязывались принимать активное участие в работе местных партийных организаций по проведению юбилейных кампаний и освещения исторический дат. Главная их задача состояла в издании юбилейных материалов в местной печати и подготовке вечеров встреч и юбилейных докладов. При этом истпарты должны были полностью согласовывать свои планы с планами местной партийной организации $[29$, л. 7]. Таким образом, истпарты окончательно закреплялись как элемент партийного аппарата.

В 1928 г. главными официальными юбилеями стали тридцатилетие I съезда партии и двадцатипятилетние II съезда. По этому поводу было принято постановление ЦК ВКП(б), в котором отмечалось, что I съезду партии не следует придавать характер широкой массовой агитации, а ограничиться проведением докладов на районных партийных и комсомольских собраниях и публикацией в местной периодической печати соответствующих статей [28, л. 4]. Методологической основой этих докладов и печатной продукции стали разработанные ранее тезисы Истпарта и Агитпропа ЦК ВКП(б). В большинстве регионов Северного Кавказа статьи в местной печати были полным аналогом этих тезисов. Следует отметить, что значение самих тезисов выходило за рамки юбилейных мероприятий. Они являлись своего рода установкой по вопросам истории партии. Отправной точкой для изучения истории местных социал-демократических организаций, согласно тезисам, являлась середина 1890-х годов, когда во всех крупных городах и промышленных центрах возникали социал-демократические организации.

При подготовке же к двадцатипятилетнему юбилею I| съезда партии истпартам предписывалось проделать «большую основательную работу» $[28$, л. 4]. Партийная директива требовала провести кампанию «в духе широкого и всестороннего освещения всей эпохи 1900-1904 гг.» [22]. В обращении Истпарта ЦК ВКП(б) к местным 
истпартам делалась идеологическая установка на то, что II съезд, принявший программу и устав, имел исключительное значение в истории партии, положив начало оформлению большевизма. В связи с этим истпарты на местах должны были активно участвовать в проведении этого юбилея в известных уже формах. Это были все те же публикации статей в региональной прессе, организация юбилейных выставок, доклады на предприятиях, вечера воспоминаний [22]. В это время центр был в состоянии помочь местным истпартам не только рекомендациями, но и материалами. Такой подход был не только помощью, но и средством унификации транслируемых в общественное сознание идей.

Так, центральный Музей революции разослал истпартам для местных выставок стандартные комплекты снимков [23]. Работники музея подготовили подробные инструкции не только по содержанию, но и планировке и внешнему оформлению выставочного материала. Ключевой идеей, которая должна была закрепиться в массовом сознании, было положение о фундаментальном значении «искровского периода» и роли В. И. Ленина в создании партии нового типа. Только благодаря В. И. Ленину и «Искре» удалось спасти РСДРП от реформизма в борьбе с «оппортунизмом меньшевиков и другими мелкобуржуазными партиями» [30, л. 30]. Это предписание отражало текущую политическую конъюнктуру в условиях внутрипартийной борьбы за власть.

Участие истпартов в юбилейных мероприятиях, посвященных истории местных вех революционного движения, должно было отражать локальную специфику при реализации политики памяти. В частности, Северо-Кавказский истпарт рекомендовал истпартам края в дни пятилетия восстановления Советской власти в округах и областях Северо-Кавказского края провести совместно с агитпропами вечера с докладами и воспоминаниями. Работники истпартов должны были разъяснять сложности Гражданской войны на Северном Кавказе, историческую неизбежность победы Советской власти в регионах, их достижения за пять лет советской власти в области советского, профессионального и партийного строительства [38, л. 26].

Для исполнения этой рекомендации Кубанский истпарт в 1925 г. участвовал в организации празднования пятилетия Советской власти на Кубани. Для экспозиций музея были созданы новые диаграммы производственных достижений, для проекции на экран были подготовлены более 20 фотографий «видных деятелей» Гражданской войны [25]. Донской истпарт подготовил тезисы кдокладу, посвященному итогам советской работы на Дону за пять лет в их исторической части, в связи с пятилетием освобождения Ростова от белых. В местной периодической печати истпарт опубликовал ряд статей и документов по соответствующей тематике [27]. Терский истпарт дал циркулярные указания всем райкомам РКП(б) округа об ознаменовании пятилетия со дня восстановле- ния советской власти на Тереке устройством вечеров воспоминаний на предприятиях, в клубах, избах читальнях, в красных уголках, на которых участники революционных событий должны были выступать со своими воспоминаниями, предварительно написанными ими по предложенной схеме [36, л. 55].

Среди историко-революционных юбилеев местного значения Северо-Кавказский краевой истпарт в 1929 г. организовал юбилей десятилетия со дня разгрома большевистского подполья в г. Ростове-на-Дону. В г. Майкопе в том же году отмечалось десятилетие разгрома советов и зверства ген. Покровского, на Кубани - десятилетие Таманской армии [26, с. 304].

В 1930 г. главной юбилейной датой локального уровня было десятилетие установления Советской власти на Северном Кавказе. Кроме того, в это время праздновалось и десятилетие। Конной Армии. Основная работа по проведению этих местных юбилеев ложилась на плечи уполномоченных краевого истпарта. Для их проведения была создана краевая комиссия, в состав которой вошел заведующий истпартом Северо-Кавказского крайкома ВКП(б) А. Лиманский. В комиссии он отвечал за редакционно-издательскую работу. В действительности грандиозный издательский план не был реализован не только из-за пассивности истпарта, но и из-за полного отсутствия помощи со стороны общественных организаций. В итоге были вынуждены ограничиться публикацией тезисов и массовых брошюр [10, л. 41]. Следует отметить, что в это время истпарт много времени затратил на организацию двадцатипятилетнего юбилея революции 1905 г., хотя масштабы этого юбилея были гораздо скромнее юбилейных мероприятий 1925 г.

Изучение пропагандистской деятельности истпартов Северного Кавказа позволяет говорить о них как инструменте реализации политики памяти советской власти на локальном уровне. В период всего времени функционирования истпартов очевидна тенденция поставить все направления их работы в подчинение текущим потребностям партии большевиков. Истпарты не только создавали интерпретации истории по партийным мотивам, но и предпринимали практические меры с целью убедить общественность в правильности интерпретаций. Именно в период подготовки и организации новых праздников все направления реализации политики памяти получали развитие и содержательное наполнение. Истпарты активно участвовали на всем протяжении своего функционирования в подготовке и проведении историко-революционных юбилеев как общероссийского, так и местного значения. В зависимости от трансформации идеологической парадигмы изменялось и содержание пропагандистской работы истпартов. Вместе с тем неодинаковая активность деятельности истпартов изучаемого региона приводила к разной интенсивности использования форм пропагандисткой работы.

В 1920-е гг. истпарты приняли активное участие в подготовке юбилея революции 1905 г 
Комплекс пропагандистских мероприятий истпартов по формированию образа революции 1905 г. как «генеральной репетиции Октября» был важен в период необходимости для новой власти поддержания собственной легитимности. Однако празднование юбилея революции 1905 г не стало советской традицией. Наиболее широко начинают отмечаться годовщины Октябрьской революции, в организации которых активно уча- ствовали истпарты. Интерпретация этого исторического события и ее закрепление в качестве доминирующей при реализации политики памяти истпартами стало основой для формирования советской идентичности. Масштаб пропагандистских мероприятий, посвященных значимым для правящей партии историко-революционным событиям, отражавшим локальную специфику, был значительно меньшим.

\section{Источники и литература}

1. Бергер П., Лукман Т. Социальное конструирование реальности: Трактат по социологии знания. М: Медиум, 1995 $323 \mathrm{c}$.

2. Бордюгов Г. А. Октябрь. Сталин. Победа. Культ юбилеев в пространстве памяти. М.: АИРО-ХХІ, 2010. 256 с.

3. Булыгина Т. А., Клопихина В. С. Организация Истпарта как инструмента выработки советского конструкта исторической памяти: Региональный контекст // Российско-Австрийский альманах: исторические и культурные параллели. Вып. VI. K 150-летию образования Австро-Венгерской империи. Ставрополь, 2018. С. 115-121.

4. Бурдье П. Социология социального пространства. М. : Институт экспериментальной социологии; СПб.: Алетейя, 2007. $288 \mathrm{c}$

5. Власть Советов. 19 декабря 1925 г. №1701. С. 1

6. Вокруг органов истпартовской работы. Донской истпартотдел // Пролетарская революция.1924. №12. С. 333-334.

7. Всероссийское совещание истпартовских работников. Юго-Восточное краевое и Донское бюро // Пролетарская революция. 1923. №4. С. 353.

8. Государственный архив новейшей истории Ставропольского края (далее - ГАНИСК). Ф. 5938. Оп. 1. Д. 794.

9. ГАНИСК. Ф. 6325. Оп. 1. Д. 8.

10. Государственный архив Ставропольского края (далее - ГАСК). Ф.р-1161. Оп. 1. Д. 1432. Л. 41.

11. ГАСК. Ф.р-1161. ОП. 1. Д. 288

12. ГАСК. Ф.р-1161. Оп. 1. Д. 717

13. ГАСК. Ф.р-1161. Оп. 1. Д. 999

14. ГАСК. Ф.р-299. Оп. 1. Д. 141.

15. Герман Р. Э. Историческое прошлое как компонент нормативно-символической сферы политики // Ученые записки Российского государственного социального университета. 2011. №3. С. 69-74.

16. Ефремова В. Н. Государственные праздники как инструмент символической политики: возможности теоретического описания // Символическая политика: Сб. науч. трудов. М.: ИНИОН РАН, 2014. Вып. 2: С. 66-79.

17. К организации празднования 20 -летней годовщины революции 1905 г. // Пролетарская революция. 1924. №7 C. $281-282$

18. Клопихина В. С. Исторический нарратив об Октябрьской революции 1917 г. как основа советской идеологии 1920-х гг.: региональный аспект // Гуманитарные и юридические исследования. 2018. №2. С. 45-51.

19. Кубано-Черноморский истпарт // Пролетарская революция. 1924. №4. С. 290

20. Миллер А. И., Малинова О. Ю., Ефременко Д. В. Политика памяти и историческая наука // Российская история 2018. №5. C.128-140.

21. Обзор деятельности местных органов Истпарта // Пролетарская революция. 1922. №8. С. 232-236.

22. Обращение Истпарта ЦК ко всем местным истпартам о проведении 25-летней годовщины II съезда // Пролетарская революция. 1928. №6-7. С. 379-380.

23. Отчет отдела местных истпарта Института Ленина и обзор истпартработы на местах за 1927/1928 гг. // Пролетарская революция. 1928. №11-12. С. 359-361.

24. Протокол третьего совещания истпартотделов СССР // Пролетарская революция. 1924. №8-9. С. 410-415

25. Работа истпртотделов. Кубанский истпарт // Пролетарская революция. 1925. №7. С. 233.

26. Работа крайистпарта Северо-Кавказского крайкома ВКП(б) за 1929 г. // Пролетарская революция. 1929. №11 C. $303-306$.

27. Работа местных истпартотделов по подготовке к 10-летию Октября // Пролетарская революция. 1926. №2. С. 274

28. Российский государственный архив социально-политической истории (далее - РГАСПИ). Ф. 70. ОП. 1. Д. 135

29. РГАСПИ. Ф. 70. ОП. 1. Д. 187.

30. РГАСПИ. Ф. 70. ОП. 1. Д. 64

31. РГАСПИ. Ф. 70. ОП. 2. Д. 129

32. РГАСПИ. Ф. 70. ОП. 2. Д. 191

33. РГАСПИ. Ф. 70. ОП. 2. Д. 197.

34. РГАСПИ. Ф. 70. ОП. 2. Д. 31.

35. РГАСПИ. Ф. 70. ОП. 2. Д. 359

36. РГАСПИ. Ф. 70. ОП. 2. Д. 362.

37. РГАСПИ. Ф. 70. ОП. 2. Д. 363.

38. РГАСПИ. Ф. 70. ОП. 2. Д. 421.

39. Рольф М. Советские массовые праздники. М.: РОССПЭН, 2009. 439 с

40. Савельева И. М., Полетаев А. В. Социальные представления о прошлом, или Знают ли американцы историю. М.: НЛО, 2008. $455 \mathrm{c}$. 
41. Ставрополье. 1925. №11. С. 3.

42. Центр документации новейшей истории Ростовской области (далее - ЦДНИРО). Ф. 319. Оп. 1. Д. 3

43. ЦДНИРО. Ф. 7. Оп. 1. Д. 173

44. ЦДНИРО. Ф. 7. Оп. 1. Д. 176

45. ЦДНИРО. Ф. 7. Оп. 1. Д. 343.

46. ЦДНИРО. Ф. 7. Оп. 1. Д. 554

47. ЦДНИРО. Ф. 7. Оп. 1. Д. 565.

48. ЦДНИРО. Ф. 7. Оп. 1. Д. 728

49. ЦДНИРО. Ф. 7. Оп. 1. Д. 825

50. Циркуляры Истпарта // Пролетарская революция. 1924. №2. С. 241

51. Юбилейные выставки по Октябрю // Пролетарская революция. 1927. №7. С. 282-283

52. The invention of tradition / Ed. by Hobsbawm E. and Ranger T. Cambridge: Cambridge univ. press, 2000. $320 \mathrm{p}$.

\section{References}

1. Berger P., Lukman T. Sotsial'noe konstruirovanie real'nosti: Traktat po sotsiologii znaniya (The Social Construction of Reality: a Treatise on the Sociology of Knowledge). Moscow: Medium publ., 1995. 323 p. (In Russian)

2. Bordyugov G. A. Oktyabr'. Stalin. Pobeda. Kul't yubileev v prostranstve pamyati (October. Stalin. Victory. The Cult of Anniversaries in the Memory Space). Moscow: AIRO-XXI publ., 2010. 256 p. (In Russian).

3. Bulygina T. A., Klopikhina V. S. Organizatsiya Istparta kak instrumenta vyrabotki sovetskogo konstrukta istoricheskoi pamyati: Regional'nyi kontekst (The Organization of the Istpart, as in Shaping a Soviet Construct Historical Memory: the Regional Context) // Rossiisko-Avstriiskii al'manakh: istoricheskie i kul'turnye paralleli. Issue. VI. K 150-letiyu obrazovaniya Avstro-Vengerskoi imperii. Stavropol': NCFU publ., 2018. P.115-121. (In Russian).

4. Burd'e P. Sotsiologiya sotsial'nogo prostranstva (Sociology of Social Space). Moscow: Institute of Experimental Sociology publ.; SPb.: Aleteiya, 2007. 288 p. (In Russian).

5. Vlast' Sovetov. December 19. 1925. No. 1701. (In Russian).

6. Vokrug organov istpartovskoi raboty. Donskoi istpartotdel (Around the Bodies of /stpart Work. Istpart Authorities of the Don) // Proletarskaya revolyutsiya.1924. No.12. P. 333-334. (In Russian).

7. Vserossiiskoe soveshchanie istpartovskikh rabotnikov. Yugo-Vostochnoe kraevoe i Donskoe byuro (All-Russian Meeting of istpart workers. South-Eastern regional and the Don bureau) // Proletarskaya revolyutsiya. 1923. No. 4. P. 353. (In Russian).

8. State archive of the regional recent history (GANISK). F. 5938. Inv. 1. D. 794. (In Russian).

9. GANISK. F. 6325. Inv. 1. D. 8. (In Russian).

10. Stavropol territory state archive (GASK). F.r-1161. Inv. 1. D. 1432. L. 41. (In Russian).

11. GASK. F.r-1161. Inv. 1. D. 288. (In Russian).

12. GASK. F.r-1161. Inv. 1. D. 717. (In Russian).

13. GASK. F.r-1161. Inv. 1. D. 999. (In Russian).

14. GASK. F.r-299. Inv. 1. D. 141. (In Russian).

15. German R. E., Istoricheskoe proshloe kak komponent normativno-simvolicheskoi sfery politiki (The Historical Past as a Component of the Normative and Symbolic Sphere of Politics) // Uchenye zapiski Rossiiskogo gosudarstvennogo sotsial'nogo universiteta. 2011. No.3. P. 69-74. (In Russian).

16. Efremova V. N. Gosudarstvennye prazdniki kak instrument simvolicheskoi politiki: vozmozhnosti teoreticheskogo opisaniya (Public Holidays as an Instrument of Symbolic Policy: Possibilities of Theoretical Description) // Simvolicheskaya politika. Issue. 2: Moscow: INION RAN publ., 2014. P. 66-79. (In Russian).

17. K organizatsii prazdnovaniya 20 -letnei godovshchiny revolyutsii $1905 \mathrm{~g}$. (On the Organization of Celebration of the 20th Anniversary of Revolution of 1905) // Proletarskaya revolyutsiya. 1924. No.7. P. 281-282. (In Russian).

18. Klopikhina V.S. Istoricheskii narrativ ob Oktyabr'skoi revolyutsii $1917 \mathrm{~g}$. kak osnova sovetskoi ideologii 1920-kh gg.: regional'nyi aspekt (Historical Narrative on the October Revolution of 1917 as the Basis of Soviet ldeology of the 1920s: Regional Aspect) // Gumanitarnye i yuridicheskie issledovaniya. 2018. No. 2. P. 45-51. (In Russian).

19. Kubano-Chernomorskii istpart (Kuban-Chernomorsky Istpart) // Proletarskaya revolyutsiya. 1924. No. 4. P. 290. (In Russian).

20. Miller A. I., Malinova O. Yu., Efremenko D. V. Politika pamyati i istoricheskaya nauka (Politics of memory and historical science) // Rossiiskaya istoriya. 2018. No.5. P. 128-140. (In Russian).

21. Obzor deyatel'nosti mestnykh organov Istparta (Review of local organ of Istpart) // Proletarskaya revolyutsiya. 1922. No.8. P. 232-236. (In Russian).

22. Obrashchenie Istparta Tsk ko vsem mestnym istpartam o provedenii 25-letnei godovshchiny II s»ezda (The appeal of the Istpart of the Central Committee to all local istparts on the conduct of the 25th anniversary of the /I Party Day) /I Proletarskaya revolyutsiya. 1928. No.6-7. P. 379-380. (In Russian).

23. Otchet otdela mestnykh istparta Instituta Lenina i obzor istpartraboty na mestakh za 1927/1928 gg. (Report of the division of local istparts of the Lenin Institute and an overview of the work of isparts over 1927/1928) // Proletarskaya revolyutsiya. 1928. No.11-12. P. 359-361. (In Russian).

24. Protokol tret'ego soveshchaniya istpartotdelov SSSR (The Protocol of the third meeting of istparts of USSR) II Proletarskaya revolyutsiya. 1924. No.8-9. P. 410-415. (In Russian).

25. Rabota istprtotdelov. Kubanskii istpart (Work of istparts. Kuban istpart) // Proletarskaya revolyutsiya. 1925. No. 7. P. 233 (In Russian).

26. Rabota kraiistparta Severo-Kavkazskogo kraikoma VKP(b) za $1929 \mathrm{~g}$. (The work of regional istparts of the North Caucasus regional Committee of the VKP (b) for 1929) // Proletarskaya revolyutsiya. 1929. No.11. P. 303-306. (In Russian). 
27. Rabota mestnykh istpartotdelov po podgotovke k 10-letiyu Oktyabrya (The work of local isparts in preparation for the 10th anniversary of the October) // Proletarskaya revolyutsiya. 1926. No. 2. P. 274. (In Russian).

28. Russan state archive social and political history (RGASPI). F. 70. Inv. 1. D. 135. (In Russian)

29. RGASPI. F. 70. Inv. 1. D. 187. (In Russian).

30. RGASPI. F. 70. Inv. 1. D. 64. (In Russian).

31. RGASPI. F. 70. Inv. 2. D. 129. (In Russian)

32. RGASPI. F. 70. Inv. 2. D. 191. (In Russian)

33. RGASPI. F. 70. Inv. 2. D. 197. (In Russian)

34. RGASPI. F. 70. Inv. 2. D. 31. (In Russian).

35. RGASPI. F. 70. Inv. 2. D. 359. (In Russian)

36. RGASPI. F. 70. Inv. 2. D. 362. (In Russian)

37. RGASPI. F. 70. Inv. 2. D. 363. (In Russian)

38. RGASPI. F. 70. Inv. 2. D. 421. (In Russian).

39. Rol'f M. Sovetskie massovye prazdniki (Soviet mass holidays). Moscow: ROSSPEN publ., 2009. 439 p. (In Russian)

40. Savel'eva I. M., Poletaev A. V. Sotsial'nye predstavleniya o proshlom, ili Znayut li amerikantsy istoriyu (Social perceptions of the past, or do Americans know history). Moscow: NLO publ., 2008. 455 p. (In Russian).

41. Stavropol'e. 1925. No. 11. P. 3. (In Russian)

42. Center for Documentation of Recent History of the Rostov Region (TsDNIRO). F.319. Inv.1. D.3. (In Russian)

43. TsDNIRO. F. 7. Inv. 1. D. 173. (In Russian).

44. TsDNIRO. F. 7. Inv. 1. D. 176. (In Russian).

45. TsDNIRO. F. 7. Inv. 1. D. 343. (In Russian).

46. TsDNIRO. F. 7. Inv. 1. D. 554. (In Russian).

47. TsDNIRO. F. 7. Inv. 1. D. 565. (In Russian).

48. TsDNIRO. F. 7. Inv. 1. D. 728. (In Russian).

49. TsDNIRO. F. 7. Inv. 1. D. 825. (In Russian).

50. Tsirkulyary Istparta (Circulars of /stpart) // Proletarskaya revolyutsiya. 1924. No. 2. P. 241. (In Russian)

51. Yubileinye vystavki po Oktyabryu (Anniversary exhibitions in October) // Proletarskaya revolyutsiya. 1927. No. 7. P. 282283. (In Russian).

52. The invention of tradition / Ed. by Hobsbawm E. and Ranger T. Cambridge: Cambridge univ. press, 2000. $320 \mathrm{p}$

\section{Сведение об авторе}

Клопихина Василина Сергеевна - кандидат исторических наук, доцент кафедры исторических дисциплин и методики их преподавания Ставропольского государственного педагогического института (Ставрополь) / vasklo@mail.ru

\section{Information about the author}

Klopikhina Vasilina - PhD in Historical Sciences, Associate Professor, Chair of Historical Disciplines and Methods of Teaching, Stavropol State Pedagogical Institute (Stavropol) / vasklo@mail.ru 